\begin{tabular}{|c|c|}
\hline$\prod_{\text {People }} \prod_{\substack{\text { Profit } \\
\text { ᄃSRᄃ }}} \prod_{\text {Planet }}$ & $\begin{array}{c}\text { Volume and Issues Obtainable at Center for Sustainability Research and } \\
\text { Consultancywww.globalcsrc.org } \\
\text { Journal of Business and Social Review in Emerging Economies } \\
\text { ISSN: 2519-089X; (Online) 2519-0326 } \\
\text { Volume 1: Issue 1 June 2015 }\end{array}$ \\
\hline
\end{tabular}

\title{
The Influence of the Creative Power of Love on Shelley's Idealism
}

\author{
${ }^{1}$ Saman Salah, ${ }^{2}$ Yus'Aiman JusohYusoff \\ ${ }^{1} \mathrm{Ph} . \mathrm{D}$ Scholar, Department of Applied Linguistics, Universiti Utara Malaysia. \\ samansbk@yahoo.com \\ ${ }^{2}$ Lecturer, Department of Applied Linguistics, Universiti Utara Malaysia. \\ yusaiman@uum.edu.my
}

\begin{tabular}{l}
\hline ARTICLEDETAILS \\
\hline History \\
Revised Format: May 2015 \\
AvailableOnline: June 2015 \\
\\
\hline Keywords \\
Percy Bysshe Shelley's poetry \\
Idealism \\
Love \\
Freedom
\end{tabular}

JEL Classification:

P10, P19

\begin{abstract}
This study examines Shelley's idealism with respect to his concept of love and the role of nature played in his love poems. The study describes Shelley's believe in the force of love to transform the world into a better place where freedom and justice prevails. The ideal imaginary world of Shelley's mind shows how love dominates, while contempt achieves devastation. As a poet of the romantic era, he strongly believes in the power of nature, which ultimately reforms the world into a new order of peace, freedom and justice. His optimism, love and freedom longs to bring betterment in society for the perfectibility of human beings. His optimism depends upon the eradication of a wide range of oppression and persecution to lead to a compassionate universe. It can be seen that the world of Shelley's imagination is administered with equity and affection, therefore, kindness triumphs over malice when man's heart is ruled by the power of love.
\end{abstract}

(C) 2015 The authors, under a Creative Commons AttributionNonCommercial 4.0

\subsection{Introduction}

\subsection{Poetry Defined}

Poetry is regarded as the representation of persuasive emotions reviewed in serenity (Wordsworth, 1802; Knapson\& Evans, 1967). It has been depicted as a creative creation which is intended to energize the faculties (Abrams, 1981). It has additionally been portrayed as a result of creative ability and passionate and inventive discourse in metrical structure, which contains unusual and private thoughts of the poet (Senanu\& Vincent, 1976; Abrams, 1981, Akporobaro, 2008; Dasylva\&Jegede, 2005). It is these feelings 
and private thoughts of the artist that we must get in and attempt to disentangle through beautiful appreciation (Leech, 1969; Toolan, 1998; Chase \& Collier, 1985).

However, the problems associated with reading, teaching and understanding poetry have been very commonly discussed by the scholars (Andrew, 1991; Benton, 1999; Benton, 2000; Benton, 1984; Dymoke, 2000; Thompson, 1996; Harrison \& Gordon, 1983; Pike, 2000; Dymoke\& Hughes, 2009). Unlike other genres, poetry is more trouble creating for the students and readers to understand (Hughes, 2007; Ray, 1999; Probst, 1992). Poetry is one of the core courses of any faculty that teaches literature, and, therefore, it is important for instructors of literature to attempt to find the major problems students confront in studying this particular literary form (Xerri, 2013; Omolara, 2013). It is assumed that students in general, regardless of their language and culture, experience some dread of approaching poetry. Steinley (1982) remarks that "cultural attitudes are often dismissive of poetry" (p. 50) and cites a survey carried out by the National Education Association (NEA) which revealed that roughly only $12 \%$ of society ever chooses to read poetry. Steinley (1982) describes the bias that a majority of students feel and express in their comments, such as "poetry is deep," "mysterious," or "all poets are depressed and wear black" (p. 50). In addition to the faulty assumptions many people hold on poetry, Peskin, Allen, and Wells-Jopling (2010) point out that "mistaken beliefs and perceptions about teaching poetry may partly create negative attitudes in teachers and student alike". According to Peskin et al; (2010), "some teachers misperceive the idea that poetry has a quite subjective and personal nature. This perspective, if taken to an extreme, means students can only acquire an understandin of poetrythrough their own silent and unexpressed perceptions" (p. 498). Such a view can undermine the whole educational process and reduce it to a futile endeavor to teach an unteachable subject (Omolara, 2013). The study of poetry usually comprises the basic tools that help students understand, appreciate, and evaluate poems and the process involves several areas that relate to criticism and the means by which poems can be analyzed in order to be appreciated and comprehended (Martin, 1984; Lynn \& Lewis, 1966). Moreover, because poetry manipulates various rhetorical devices, figurative language, symbolism and syntactical tricks, the subject requires from the learners the basic knowledge of all these components in order to handle effectively the material they study (Sayakhan, 2007). As Linaberger (2004) observes, "poetry can be daunting to some students (and some teachers, too). The concepts and complex language in poems may be difficult for students to grasp or it can be confusing, at best" (p. 366).

\subsection{Love defined}

Love is the most intense feeling and most sought after from conception to death till man finishes his excursion of life on earth (Luhmann, 1986). The influence of love has been cited and rehashed in the history of literature. The concept of love is interesting in writing. Love has managed through all ages and times, however yet, has an unparalleled capacity that stays consistent even as it winds through various centuries. Love is likewise reflected in different concepts in writing, for example, contempt, pity, roughness, desire and idealism (Kanwar, 2014). However, of all the romantic poets, PB Shelley sketched out the mystery of love in ethics, a recognizable proof of self with the beautiful and excellent that existed in thought, activity or individual (Kanwar, 2014). As indicated by Shelley; it was not passion, which united individuals, but rather something more. It changed the character of an individual, changed the wimp to a chivalrous man, intend to honorability, rude to benevolent. In this way, love turned into a political belief system to change individuals for the regeneration of a better society. Shelley's thought of love lay in the soul of his idealistic perspectives on social equity and political freedom. (Bysshe Shelley, p. 82-88).

\subsection{Shelley: A biographical Sketch and Review of the Past Studies}

PB Shelley was born in England on $4^{\text {th }}$ August, 1792. He was the son of a famous parliamentarian Sir 
Timothy Shelley. Shelley belonged to an aristocratic family. He was a skeptic from his early age. He was expelled from Oxford for writing an essay named "Necessity of Atheism" (Scrivener, 2014; Miller, 2013). He spent his whole life writing for the cause of the lower classes and poor people. He had deep affiliation with nature from his boyhood days, which later resulted in magnificent poems based on the themes of love and nature, thus bringing him in the list of the best romantic poets in English poetry (O’Neil, 1993).

Since Shelley is one of the chief progressive artists, and different studies have been conducted on his literary works. He is eminent for his extraordinary method for communicating his vision and cynic considerations (Miller, 2013; Lee, 2012; Dwyer 2004; Itsuki, 2011; Morris, 1999; Hopkins, 1953).

However, there is a lack of study in analyzing Shelley's vision of love which played an important role in making him a true Romantic poet. Therefore, this paper fills in this gap and analyses Shelley's love poems to show the influence of love on his whole ideology.

\subsection{Treatment of Love in Shelley's Love poems}

Being a Romantic poet, Shelley's poems are embedded with themes of love and his whole philosophy is based on the ideals of love (Cronin, 2002; Evans, 1990). Some of the love poems of Shelley are analyzed in this paper to show how love played an important role in shaping Shelley's overall ideology of life.

"Love's Philosophy" is the first major love poem by PB Shelley. In this poem Shelley refers to nature which is basically a divine power to express the mingling and union of everything in the world. The poet expresses,

"The fountains mingle with the river,

And the rivers with the ocean,

The winds of heaven mix forever

With a sweet emotion;

Nothing in the world is single;

All things by law divine

In one another's being mingle;--

Why not I with thine?" (in Hutchinson, 1914, p. 102)

Thus the objects of nature all follow the divine laws of pairing with one another. For instance, the "The fountains mingle with the river", and similarly the winds play their role in mingling with the other natural objects. Therefore the poet asks his beloved if natural objects which are divine can pair with one another, why not his beloved pair with him?

The second stanza follows the same pattern of thought regarding the mingling of the natural objects. For instance,

"See the mountains kiss high heaven 
And the waves clasp one another

No sister flower would be forgiven

If it disdained its brother;

And sunlight clasps the earth,

And the moonbeams kiss the sea;

What are all these kissings worth

If thou kiss not me?” ((in Hutchinson, 1914, p. 102)

The poet wants to say that just like nature, man should love one another. There should not be any feelings of hatred with one another. Just like "mountains" love the "high heavens" and "waves" join one another, humans should also live with love. The poem is rich with the natural imagery; "No sister flower could be forgiven if it disdained its brother" expresses that man should follow the rules made by nature. Man should take care of each other because a brother will look on to another brother. Moreover, love should be both sided, otherwise it is useless. It should be noted that while writing this poem, Shelley got married to Mary Godwin, the daughter of William Godwin (the famous anarchist). Shelley loved Mary Godwin very passionately. Thus, the biographical record clearly shows that Shelley composed this poem during the time of his deep feelings for his wife. However, it should also be noted that love as an intense emotion never overpowered Shelley's logical reasoning. As he says in the poem,

"Nothing in the world is single" (in Hutchinson, 1914, p. 102)

The above line clearly indicates that Shelley gives a logical reason based on natural objects to show the pairing of everything in the universe.

Another poem of Shelley that contains themes of love is "When the Lamp Is Shattered". Unlike his poem "Love's Philosophy" this poem deals with the presence and absence of things based on their origin and transition. For instance, a broken lamp cannot provide light to anyone. Similarly, the rainbow disappears once the rain stops. Moreover, a flute is useless and cannot produce music if it is broken. Nobody remembers good words when once uttered by the lips.

"When the lamp is shattered

The light in the dust lies dead

When the cloud is scattered

The rainbow's glory is shed.

When the lute is broken,

Sweet tones are remembered not.

When the lips have spoken

Loved accents are soon forgot” (in Hutchinson, 1914, p. 220) 
In the second stanza the poet says that if the lamp and the flute do not exist anyone, the light and music cannot be produced. A heart will not sing melodious songs if it lacks spirit or rigor of love. Instead the heart will sing only gloomy songs if it lacks the spirit of love. Infact a heart without spirit will be like a wind which blows over a "ruined cell" or a wave that indicates the death of a sailor or merchant. Here is an excerpt of the second stanza expressing the condition of heart in the absence of the spirit of love,

"As music and splendour

Survive not the lamp and the lute.

The heart's echoes render

No song when the spirit is mute

No song but sad dirges,

Like the wind through a ruined cell,

Or the mournful surges

That ring the dead seaman's knell.” (in Hutchinson, 1914, p. 220)

It is interesting to note that in this poem Shelley's logical reasoning becomes more stronger than in his poem "loves philosophy". It is because in one of the stanza's of this poem, he even calls "Love" as transitory as it shifts from time to time. "Reason" for Shelley, is the most important thing that shifts love from time to time. It is this human reasoning which finally mocks at love and finally dominates man's mind just like the sun which appears after "wintery sky". Here is an excerpt from the poem showing the power of reason and the weakness of love.

"Bright reason will mock thee,

Like the sun from a wintry sky" (in Hutchinson, 1914, p. 220)

Unlike "Love's Philosophy" which completely follows the romantic doctrines of a love poem, this poem gives more look of modernism rather than romanticism due to its skeptic and transitory approach towards love.

"Music, When Soft Voices Die" is another poem depicting the theme of love. The poem is rich with examples of "music" and "soft voices" to express his loneliness in the absence of his beloved. He says,

"Music, When Soft Voices Die

Music, when soft voices die,

Vibrates in the memory --

Odours, when sweet violets sicken,

Live within the sense they quicken.

Rose leaves, when the rose is dead, 
Are heap'd for the beloved's bed;

And so thy thoughts when thou are gone" (Shelley, 2015)

The poet expresses that when we hear music, the notes of the sweet music remains lingering for a long time even when the music is turned off. Similarly, the fragrance of the "violets" and "roses" continue to effect on our mind for long. Therefore, he says that the thoughts of his beloved remains in his heart and mind even if she is dead. However, the last line of the poem gives a note of hope. He says,

"Love itself shall slumber on" (Shelley, 2015)

The above line indicates that though everything is temporary in the world, but love is a feeling which goes on with all human beings till death. The interesting point in the poem is that the poem is written in a sad mood in the beginning, but changes its tone to hope in the end.

Another poem by Shelley, "The Invitation" also contains themes of love. This poem was written by Shelley for his friend Jane Williams. The poem is a beautiful example of friendship and love. The poet was attached with Jane Williams intellectually and had great regard for her. The poet says,

"Best and brightest, come away,

Fairer far than this fair day,

Which, like thee, to those in sorrow

Comes to bid a sweet good-morrow" (in Hutchinson, 1914, p. 221)

In the above stanza the poet calls his friend as "Bright" and "Fair". He says that his friend comes like a beautiful morning whenever the poet is sad. The poet continues to praise his friend and expresses that his friend is like a "prophetess" or in other words a humble person who helps him in rainy days just like flowers grow over the infertile land to beautify the land. Similarly the smile of his friend makes him forget all sorrows.

"And like a prophetess of May

Strewed flowers upon the barren way,

Making the wintry world appear

Like one on whom thou smilest, dear." (in Hutchinson, 1914, p. 221)

In the next stanza the poet becomes assertive and says that love has become materialized in the huge buildings and cities. To have complete fulfillment of love, care and time with a friend one should go away from hustle and bustle of the city life. He says,

“Away, away, from men and towns,

To the wild wood and the downs -

To the silent wilderness

Where the soul need not repress 
Its music, lest it should not find

An echo in another's mind,

While the touch of Nature's art

Harmonizes heart to heart.” (in Hutchinson, 1914, p. 221)

The poet also expresses the role of nature in provoking true love with our beloved ones. He says that nature fulfills our heart with love. Therefore, he requests his friend to accompany him to the "woods" and "plains", "pines" and "round stems" to fulfill their heart with love and quality time. An excerpt from the poem indicates his thoughts about the role of nature to provoke love,

"Awake! arise! and come away!

To the wild woods and the plains,

Round stems that never kiss the sun” (in Hutchinson, 1914, p. 221)

The poet describes his friend the beautiful scenes of nature such as "lawns", "pastures", "sandhills", "sea", "frost" and different flowers. The also expresses that nature treats everything alike. The theme of love moves towards a more profound form in the last two lines of the poem gives a message that if nature can treat every human, animal and all objects alike then why not human beings treat everyone alike. The poem gives a message of universal love and equality for all. As the poet says in the following lines,

"Where the lawns and pastures be

And the sandhills of the sea,

Where the melting hoar-frost wets

The daisy-star that never sets,

And wind-flowers and violets

Which yet join not scent to hue

Crown the pale year weak and new

Where the earth and ocean meet

And all things seem only one

In the universal Sun.” (in Hutchinson, 1914, p. 221)

\subsection{Discussion}

The very first love poem of Shelley "Love's Philosophy" explains the mingling of every natural object and therefore the poet requests him to join him to complete the universal phenomenon of union. The second poem "When the Lamp Is Shattered" is based on the transitory nature of everything particularly "love". The third love poem "Music, When Soft Voices Die" explains sad and hopeful side of love. The 
last love poem of Shelley "The Invitation" gives a message of universal love and equality. It is interesting to note that whether love is portrayed as a "mingling concept", "transitory love", "love as a source of sadness and hope" or "universal love", in all these treatments of love, Shelley uses "Nature" as a medium to express his opinions. This use of "nature" as a "divine power" in his poems makes him a true romantic poet.

\subsection{Conclusion}

To conclude, PB Shelley is one of the greatest of the romantic poets. His vision of love was bright and hopeful. He never compromised on his ethical standards. It is due to this spirit of universal love and equality that he could not tolerate injustice in any form. Although his skeptic mind made him restless, however, his close intimacy with nature never ended throughout his life which made him to compose the most beautiful love poems in English poetry.

\section{References}

Abrams, M. (1981). A Glossary of literary terms. New York: Holt, Renehart and Winston. Akporobaro, F.B.O. (2008). Poetry. Lagos: Princeton Publishing Co.

Andrews, R. (1991). The Problem with Poetry. Milton Keynes, UK: OpenUniversity Press.

Benton, P. (1984). Teaching Poetry: The rhetoric and the reality. Oxford Review of Education, 10 (3), $319-327$.

Benton, P. (1999). Unweaving the rainbow: Poetry teaching in the secondary school I. Oxford Review of Education, 25(4), 521-531

Benton, P. (2000). The conveyor belt curriculum? Poetry teaching in the secondary school II. Oxford Review ofEducation, 26(1), 81-93.

Chase, M. \& Collier, P. (1985). An Introduction to Literature. New York: Harcourt, Brace and Jovanovich.

Cronin, Richard. (2002). Romantic Victorians: English Literature, 1824-1840. Gordonsville: Palgrave Macmillan.

Dasylva, A. \&Jegede O. (2005). Studies in Poetry. Ibadan: Stirling- Horden Publishers (Nig). Ltd.

Dwyer, Molly. (2004). That Powerful Attraction; Shelley and the power flowing through the natural world.Ph.D thesis, Exeter College, Oxford University, UK.

Dymoke, S. (2000). The teaching of poetry in secondary schools. Unpublished PhD thesis: University of Nottingham, UK.

Dymoke, Sue. , Hughes. Janette. (2009). Using a poetry wiki: how can the medium support pre- service teachers of English in their professional learning about writing poetry and teaching poetry writing in a digital age? English teaching Practice and Critique. Volume. 8. No. 3. Page 91106.

Evans, Ifor. (1990). A Short History of English literature. Penguin Books.

Harrison, B., \& Gordon, H. (1983). Metaphor is thought: Does Northtown need poetry? Educational Review, 35(3), 265-278.

Hopkins, John. Vincent. (1953). An orderly presentation of the three objects of Shelley's Symbolism. Master's thesis. Loyola University, Chicago.

Hughes, Janette. (2007). Poetry a powerful medium for literacy and technology development. The literacy and numeracy secretariat, University of Ontario Institute of technology. Research Monograph No: 7. 
Hutchinson, Thomas. (1914). The Complete Poetical Works of Percy Bysshe Shelley. London: Oxford University Press.

Itsuki, Kitani. (2011). The pleasure of the senses: The art of sensation in Shelley's poetics of sensibility. Ph.D Thesis. Durham University, UK.

Kanwar, M. G. (2014). Portrayal of love in Literature. Research Scholar, An International Refereed eJournal of Literary Explorations Vol. 2 Issue II. ISSN 2320 - 6101

Knapson, J. \& Evans, B. (1967). Teaching a Literature- centered English Program. NewYork: Random House.

Lee, Monika. (2012). Shelley's Spiritual Atheism. The Criterion. An International Journal in English. September, Vol.III. Issue.III.

Leech, G. (1969). A linguistic Guide to English Poetry. London: Longman.

Linaberger, M. (2004). Poetry top 10: A fool proof formula for teaching poetry. The Reading Teacher, 58 (4), 366-372. doi: 10.1598/RT.58.4.6, from EBSCO online database Academic Search Complete.

Luhmann, N. (1986). Love as passion: The codification of intimacy. Harvard University Press.

Lynn, Altenbernd\& Leslie L. Lewis. (1966). A handbook for the study of Poetry. New York: Macmillan publishing Co., 4.

Martin, Stephen. (1984). An Introductory Guide to English Literature. London: Longman. York handbooks. Edition: 3 reprint.

Miller, Susan. (2013). Shelley's early fiction in relation to his poetics and politics: an assessment. Not waiting to see the event of his victory. $\mathrm{PhD}$ thesis. University of Glasgow, UK.

Morris, Lorraine Anne. (1999). All that faith creates, or love desires: Shelley's poetic vision of being. PH. D thesis. Durham University. UK.

Omolara. Iyabode., Akewo. Daniel, (2013). A Critical Look at the Teacher Factor in Senior Secondary School Students ${ }^{\text {ee }}$ Poetic Appreciation Skills Development. "Theory and Practice in Language Studies", Vol. 3, No. 2, pp. 222-232, February 2013@ 2013 ACADEMY PUBLISHER Manufactured in Finland. ISSN 1799-2591.

O’Neil, Michael. (1993). Shelley. Longman critical readers. London.

Peskin, J., Allen, G., \& Wells-Jopling, R. (2010). The educated imagination: Applying instructional research to the teaching of symbolic interpretation of poetry. Journal of Adolescent \& Adult Literacy, 53 (6), 498-507.

Pike, M. (2000). Keen readers: Adolescents and pre-twentieth century poetry. Educational Review, 52 (1), 13-28.

Porrello, Steven. (2014). The Radical Imagination: In Conflict, We Need Imagination. Journal of undergraduate research, Volume 11. Lagrange College.

Probst, R. E. (1992). Five kinds of literary knowing. In J. Langer (Ed.), Literature instruction: A focus on student response. Urbana, IL: National Council of Teachers of English. 54-77.

Ray, R. (1999). The diversity of poetry: How trainee teachers' perceptions affect their attitudes to Poetry teaching Curriculum Journal, 10 (3), 403-419.

Sayakhan, NajatIsmaeel. (2007). The teaching problems of English Poetry in the English Departments. Master's thesis. Kurdistan Regional Government Ministry of higher education and scientific research, university of Sulaimani.

Senanu,K. \& Vincent, T. (1976). A selection of African Poetry. London: Longman.

Scrivener, M. H. (2014). Radical Shelley: The Philosophical Anarchism and Utopian Thought of Percy Bysshe Shelley. Princeton University Press. 
Shelley, P.B. (2015). Music when Soft Voices Die. Retrieved from https://www.poetryfoundation.org/poems-and-poets/poems/detail/45132.

Steinley, G. L. (1982). Symbolizing: Recognizing and naming symbols. College English, 4(1), 44-56. doi:10.2307/377198.

Thompson. L. (Ed.). (1996). The teaching of poetry: European perspectives.London: Cassell Education. Toolan, M. (1998). Language in Literature: An Introduction to Stylistics. London: Hodder Arnold.

Wordsworth, W. (1802). Wordsworth's preface of 1800, with a collation of the Enlarged preface of 1802. In W.J.B. Owens (1969) Wordsworth's and Coleridge Lyrical Ballads 1798 (2 ${ }^{\text {nd }}$ edition). Oxford: Oxford University Press.

Xerri, Daniel. (2013). Poetry Writing in the post-16 English Curriculum. English teaching in practice and critique. Vol 12, number 2, page 140-155. 
